\title{
Assessment of Plasma Endostatin Levels in Patients with Acute Myeloblastic and Lymphoblastic Leukemia
}

\author{
Simten DAGDAS, Gulsum OZET, Mesude YILMAZ, Murat ALBAYRAK, Funda CERAN
}

Ankara Numune Training and Research Hospital, Department of Hematology, Ankara, TURKEY

\begin{abstract}
In this study, we evaluated the plasma levels of endostatin (PE) and its prognostic importance in patients with acute myeloblastic $(A M L)$ and lypmhoblastic leukemia (ALL). We therefore analyzed plasma levels of endostatin before the chemotherapy and during the complete remission period in adult ALL and AML patients. The PE levels of the control group were significantly lower than both cases with $A L L$ and AML. The patients with AML during remission had significantly higher PE levels than the levels at initial diagnosis. No statistically significant difference was detected in patients with ALL. In addition, the survival rates of the cases with ALL whose PE levels are higher than $2.5 \mathrm{ng} / \mathrm{ml}$, are significantly lower. Our results suggest that the elevated plasma levels of endostatin during the remission in patients with AML imply the intensity of angiogenesis inhibition during the remission. Furthermore our findings in ALL patients suggest that endostatin levels may predict the overall survival of these patients.
\end{abstract}

Keywords: Acute myeloblastic leukemia, Acute lymphoblastic leukemia, Angiogenesis, Endostatin

ÖZET

\section{Akut Myeloblastik ve Lenfoblastik Lösemili Hastalarda Plazma Endostatin Düzeylerinin Değerlendirilmesi}

Bu çalışmada akut myeloblastik (AML) ve akut lenfoblastik lösemili (ALL) hastalarda plazma endostatin (PE) düzeylerini ve prognostik anlamını değerlendirdik. Bu amaçla erişkin ALL ve AML hastalarında kemoterapi öncesi ve komplet remisyon sırasında plazma endostatin düzeylerini analiz ettik. Kontrol grubunun plazma endostatin (PE) düzeyi hem ALL hem de AML hastalarına göre istatistiksel olarak anlamlı oranda daha düşüktü. AML'li hastalarda remisyon sırasındaki PE düzeyleri tanı anına göre anlamlı olarak daha yüksekti, ALL'li hastalarda istatistiksel olarak anlamlı bir fark tespit edilmedi. Ayrıca 2,5 ng/ml'nin üzerinde PE düzeylerine sahip ALL hastalarında yaşam süresi anlamlı olarak daha düşüktü. AML olgularında remisyon sırasında endostatin düzeylerinin yüksek olması remisyon sürecinde anjiogenez inhibisyonunun yoğunluğunu gösterebilir. Ayrıca bulgularımız ALL'de endostatin düzeylerinin toplam yaşam süresini ön görmede etkili olabileceğini düşündürmüştür.

Anahtar Kelimeler: Akut myeloblatik lösemi, Akut lenfoblastik lösemi, Anjiogenezis, Endostatin 


\section{INTRODUCTION}

Angiogenesis is the formation of new vessels from an existing network of vasculature. ${ }^{1}$ Physiological angiogenesis may be seen during fetal development, reproductive cycles of adult women and pregnancy. In addition it may be seen in wound healing and tissue repair and diseases such as cardiovascular atherosclerotic disorders, psoriasis, diabetic retinopathy, chronic inflammatory diseases, endometriosis and cancer. ${ }^{2}$ This process includes the steps of degradation of matrix proteins, activation of endothelial cells, proliferation and migration. ${ }^{3}$

Angiogenesis is a highly regulated process under the tight control of activators and inhibitors. A variety of proangiogenic and anti-angiogenic agents have been identified. Vascular endothelial growth factor (VEGF) and basic fibroblast growth factor (bFGF) are the most potent proangiogenic regulators. Angioproteins, platelet derived growth factor (PDGF), transforming growth factor- $\beta$ (TGF- $\beta$ ), and membrane bound proteins such as integrins and cadherins have also been identified as stimulators of angiogenesis. ${ }^{3}$ Interferons, interleukin-4 (IL-4), tissue inhibitors of metallooproteinases, proteolytic fragments of angiostatin and endostatin are identified as the inhibitors of angiogenesis. ${ }^{4,5}$

Tumor cells induce angiogenesis in a process which resemble the normal angiogenesis. This angiogenesis is regulated with pro and anti-angiogenic molecules that are secreted from tumor cells itself as well as the pericytes and monocytes encircling the tumor cells. Some cytokines such as IL -8 are shown to play a role in tumoral angiogenesis that are different from the molecules that take place in normal angiogenesis. Angiogenesis plays an important role in progressing the premalignant lesions to malignancies, tumoral development, entering tumor cells into circulation and transforming the micrometastases to obvious metastatic lesions.$^{5,6}$

Most of the initial studies in angiogenesis were done on solid tumors. ${ }^{7-9}$ Recently, it has also been recognized that disregulation of angiogenesis constitutes an important step in the development and progression of hematological malignancies and that leukemias may invade and proliferate in the bone marrow and other organs by mechanisms similar to those reported in solid tumors. ${ }^{10}$ The interaction of endothelial cells and the marrow microenvironment with hematopoie- tic progenitors and leukemia cells play a role in the development of the leukemic phenotype by virtue of the secretion of proangiogenic and antiangiogenic cytokins. The blood levels of pro-angiogenic and anti-angiogenic growth factors can be measured and may have prognostic and diagnostic values. It has been reported that the blood levels of some proangiogenic factors such as VEGF, bFGF and hepatocyte growth factor (HGF) might be elevated and correlated with unfavorable prognosis in patients with AML and myelodysplastic syndrome (MDS). ${ }^{10,11}$ Most studies about the role of angiogenic factors in ALL have been conducted in children, and data are limited in adults. It was reported that elevated VEGF levels are associated with good prognosis and longer survival in a study of the adult patients with ALL, in contrast with the results that have been obtained from children. ${ }^{12}$ This supports the biological differences between pediatric and adult ALL.

The clinical significance of the soluble anti-angiogenic factors is less known in hematologic malignancies. Endostatin is one of the most potent inhibitors of angiogenesis and is generated from the cleavage of the C-terminal fragment of collagen XVIII. ${ }^{13}$ It was first isolated from a vascular neoplasm, a murine hemangioendothelioma. ${ }^{13,14}$ It prevents angiogenesis and may drive large tumors into dormancy in mice. ${ }^{15-}$ ${ }^{17}$ Higher levels of serum endostatin have been demonstrated in patients diagnosed with breast carcinoma, nonsmall cell lung carcinoma, soft tissue sarcoma and renal cell carcinoma compared with a healthy control group and have been associated with poor prognosis in patients with nonsmall cell lung carcinoma. ${ }^{18-22}$ The elevated levels of serum endostatin have been reported to associate with unfavorable survival in a study that has been conducted in 143 Non Hodgkin Lymphoma cases. The results are not parallel to those in acute leukemias in which a limited number of the studies have been performed in patients with AML. ${ }^{23-25}$ Studies that evaluate the anti angiogeneic factors in cases with ALL are very limited. The aim of the current study is to determine the plasma endostatin levels and its prognostic importance in patients with AML and ALL.

\section{PATIENTS AND METHODS}

Patients: Serum samples from 19 adult patients (8 females and 11 males) with ALL and 33 adult pati- 
ents (15 females and 18 males) with AML were taken before chemotherapy was administered. Each case has been diagnosed with clinical, morphological, immune phenotype studies and cytogenetic assessment. In addition, nine of 19 cases with ALL and nine of the 33 cases with AML have been analyzed once again after the complete remission (CR). Thirteen samples from healthy volunteers ( 7 females and 6 males) were evaluated as the control group.

Plasma Entostatin Levels: The blood samples were taken into test tubes with EDTA, plasma components separated and then frozen at $-80^{\circ} \mathrm{C}$ soon after collection. Samples were thawed at the time of study and plasma endostatin levels were measured with ELISA kit (Quantikine kits of R\&D Systems Minneapolis, USA) according to the kit procedure, then microplates were read on the Elx800 device at the $492 \mathrm{~nm}$. Analyses and calibrations were carried out in duplicate. Minimum detectable dose range of endostatin kit was between 0.001 and $0.063 \mathrm{ng} / \mathrm{ml}$. The patients who had undergone the allogeneic stem cell transplantation were excluded from the study. Induction treatment which was composed of cytosine arabinoside (ARA-C) and anthracycline and consolidation treatment which was composed of high dose ARA-C based treatment were administrated to the patients with AML. Transretinoic acid (ATRA) and anthracycline were utilized in patients with acute promyelocytic leukemia. Patients with ALL were treated with HYPER-CVAD regimen. All patients were regularly followed up in the hematology department of our hospital.

Statistical Analysis: Shapiro wilk test was utilized to determine whether the continuous data were normally distributed or not. Continuous variables were expressed as mean \pm standard deviation or median (range) where applicable. Nominal data was shown as number of cases and (\%). Mean levels of Endostatin were compared by using Student's t test when the independent group number was two. The statistical significance of the differences among groups were evaluated One-Way ANOVA and post hoc Tukey test. Whether the difference in PE levels between initial and remission periods was statistically significant or not was evaluated by Paired t test. Degree of association between continuous variables was calculated by Pearson's correlation coefficient. Kaplan Meier survival analyses were applied and log-rank test was used for determining the effects of nominal risk fac-

\begin{tabular}{|c|c|c|}
\hline Characteristics & AML & ALL \\
\hline Total number & 33 & 19 \\
\hline \multicolumn{3}{|l|}{ Gender } \\
\hline Male & 17 & 8 \\
\hline Female & 18 & 11 \\
\hline \multicolumn{3}{|l|}{ Age } \\
\hline Median & 38 & 26 \\
\hline Range & $21-69$ & $17-47$ \\
\hline \multicolumn{3}{|l|}{ FAB Type (for AML) } \\
\hline M O & 5 & - \\
\hline M 1, 2 & 17 & - \\
\hline M3 & 6 & - \\
\hline M 4, 5 & 3 & - \\
\hline \multicolumn{3}{|c|}{ Immune phenotype (for ALL) } \\
\hline T lineage & - & 5 \\
\hline B lineage & - & 11 \\
\hline Unknown & - & 3 \\
\hline \multicolumn{3}{|l|}{ ECOG performance status } \\
\hline Less than 2 & 28 & 18 \\
\hline More than 2 & 5 & 1 \\
\hline \multicolumn{3}{|l|}{ Cytogenetic } \\
\hline Inv16 & 2 & - \\
\hline$t(15,17)$ & 6 & - \\
\hline$t(8,21)$ & 4 & - \\
\hline$t(9,22)$ & - & 2 \\
\hline$t(4,11)$ & - & 1 \\
\hline Normal & 4 & 9 \\
\hline Complex & 5 & 1 \\
\hline Others & 4 & 4 \\
\hline Data not available & 8 & 2 \\
\hline $\begin{array}{l}\text { Average follow up time } \\
\text { (month) }\end{array}$ & $21.1(13-33)$ & $21.3(14-30)$ \\
\hline \multicolumn{3}{|l|}{ Response to treatment } \\
\hline Complete remission & 18 & 18 \\
\hline No response & 12 & 1 \\
\hline No follow up & 3 & - \\
\hline \multicolumn{3}{|l|}{ Survival } \\
\hline More than 1 year & 13 & 12 \\
\hline Less than 1 year & 17 & 7 \\
\hline Lost to follow up & 3 & - \\
\hline
\end{tabular}

tors on overall and leukemia free survival. A p value less than 0.05 was considered statistically significant.

\section{RESULTS}

Characteristics of the patients with ALL and AML are summarized in tables 1 and 2. Mean plasma levels of endostatin are depicted in Table III and Figure 1. Pre-treatment PE levels were significantly elevated in patients with AML and ALL compared to normal individuals $(\mathrm{p}=0.007$ and $\mathrm{p}<0.001$, respectively). No statistically significant difference was de- 


\begin{tabular}{|lcl|}
\hline \multicolumn{2}{|c|}{ Table 2. } & Plasma endostatin levels \\
\hline $\mathbf{N}$ & $\begin{array}{c}\text { Mean endostatin } \\
\text { levels (ng/ml) }\end{array}$ & Range) \\
\hline Control & 13 & $1.22(0.7-1.5)$ \\
ALL & 19 & $2.29(0.56-4.1)$ \\
AML & 33 & $2.45(0.4-3.9)$ \\
Remission ALL & 9 & $2.33(0.57-3.8)$ \\
Remission AML & 9 & $3.03(1.6-4.2)$ \\
\hline
\end{tabular}

tected between patients with ALL and AML ( $\mathrm{p}=$ 0.838). Whereas the mean PE level of the patients with AML during the remission period was higher than those during the initial diagnosis $(\mathrm{p}=0.041)$, a significant difference was not detected in patients with ALL regarding these periods $(\mathrm{p}=0.761)$.

No significant correlation was detected between the PE levels at the time of the diagnosis and the ECOG performance status, patient age, leukocyte counts, karyotype, hemoglobin levels, thrombocyte counts and LDH levels $(p>0.05)$. PE levels in female and male patients were similar in both diseases and control groups. Statistically significant difference was not detected of PE levels between patients with $\mathrm{T}$ cell ALL and B cell ALL or between FAB groups of AML cases $(p>0.05)$ There was no statistically significant difference between $\mathrm{CR}$ duration and the PE levels $(p=0.196, p=0.900)$. In addition, no statistically significant influence of PE levels on leukemia free survival in both disease groups was observed.

When the patients were categorized according to plasma endostatin levels $\leq 1.5 />1.5, \leq 2 />2$ and $\leq$ $2.5 />2.5 \mathrm{ng} / \mathrm{ml}$, the selection of the cut off value of $2.5 \mathrm{ng} / \mathrm{ml}$ was shown to have some significant effects on the overall survival of the patients with ALL only. The overall survival ratio of patients with endostatin levels higher than $2.5 \mathrm{ng} / \mathrm{ml}$ was significantly less than those with the endostatin levels lower than 2.5 $\mathrm{ng} / \mathrm{ml}(\mathrm{p}=0.03)$ (Figure 2$)$ while no correlation was detected in patients with AML.

\section{DISCUSSON}

Angiogenesis has been recognized to have an important role in the tumoral progression and metastatic disease since Dr. Folkman had proposed the hypothesis that tumor development is angiogenesis dependent in $1971 .^{26,27}$ The immunohistochemical quantification of

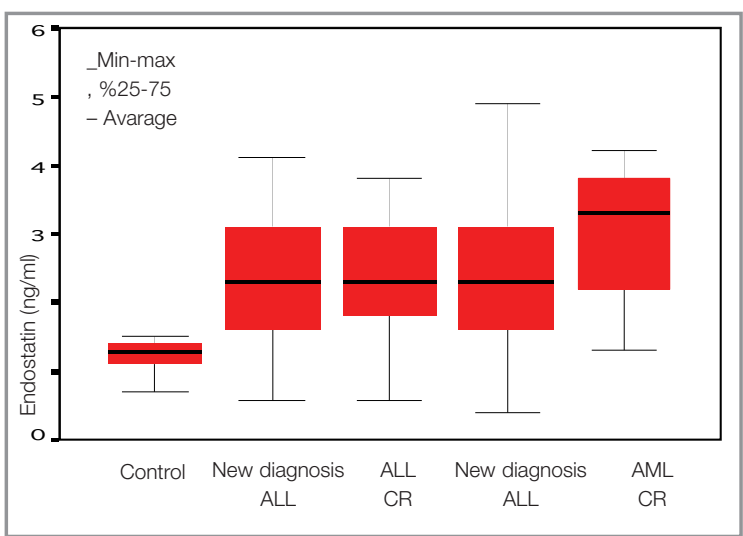

Figure 1. Plasma endostatin levels

the vascular endothelial cells and measurements of microvessel density have been widely utilized to detect the angiogenic activity. ${ }^{28,32}$

The neovascularization is regulated with the pro and anti-angiogenic factors that are released by tumor cells themselves and by accessory host cells such as macrophages, mast cells, and lymphocytes..$^{33,34}$ It has been shown in several studies that systemic levels of these mediators could be important in the regulation of angiogenesis. ${ }^{10,35,36}$ Most of the initial studies in angiogenesis were done on solid tumors. However, there are increasing numbers of studies that demonstrate the importance of angiogenesis in hematologic malignancies..$^{12,37-40}$ The levels of proangiogenic mediators and microvessel density have been shown to be increased in AML, MDS, pediatric ALL, chronic myeloid leukemia (CML), non-hodgkin lymphoma (NHL) and multiple myeloma (MM) in comparison to control cases in some studies. ${ }^{32,39,41,42}$ In some studies it has been demonstrated that increase in the level of pro-angigogenic factors could be a prognostic indicator. ${ }^{12,37,38}$ A recent study has shown that angiogenesis in bone marrow was increased in AML patients with dynamic contrast-enhanced magnetic resonance imaging (DCE-MRI) and this increase was a beneficial prognostic indicator. ${ }^{43}$

Almost all studies about the role of angiogenic factors in ALL have been conducted in children, and data is limited in adults. ${ }^{44}$ It was reported in a study performed by Stefan Faderl et al., that in contrast to pediatric ALL and AML cases, elevated levels of VEGF were associated with good prognosis in adult cases with ALL. These data reflect that the biology of the angiogenic factors in adult with ALL differan- 


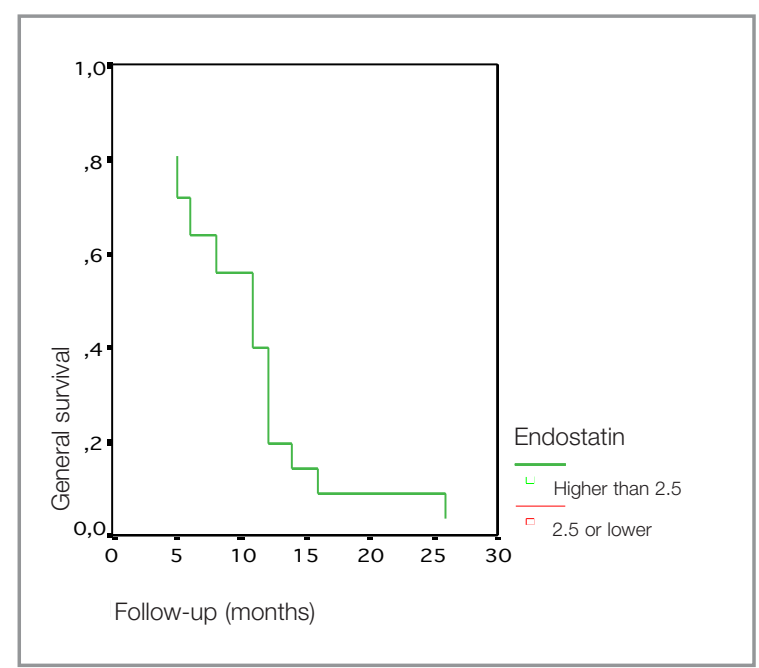

Figure 2. Survival of cases with ALL group whose endostatin levels are lower and higher than $2.5 \mathrm{ng} / \mathrm{ml}$

tiates from that in pediatric ALL and other hematologic malignancies. ${ }^{12}$

In addition to proangiogenic factors, endogen inhibitors of the angiogenesis were identified. The measurements of the levels of these factors were reported to give clues for determining the prognosis of the diseases. ${ }^{18,21}$ In addition, systemic treatment with recombinant human endostatin was shown to tumor stabilization after chemotherapy. ${ }^{45-47}$ Our knowledge about the clinical meaning of endostatin in hematologic malignancies is very limited. The results that have been reported in non-Hodgkin lymphomas are conflicting. Bono et al. showed that increased level of serum endostatin during pretreatment period was correlated with elevated VEGF and poor survival. ${ }^{22}$ However, in a previous study the levels of endostatin were not different in CR patients compared to relapsed patients and did not correlate with event free survival (EFS) in patients with Non-Hodgkin Lymphoma. ${ }^{38}$

In our study, the plasma levels of endostatin in pretreatment period were observed to be higher in cases with AML than those in normal controls, similar to the study performed by Wrobel et al. in the cases with AML. ${ }^{25}$ The median PE level of our patients with AML during CR was higher than pretreatment period as in some previous studies, but a significant difference was not detected in patients with ALL with regard to these periods. ${ }^{25,48}$

The study conducted by Glenjen et al. also supports these findings. In addition it was shown that the le- vels of proangiogenic mediators were decreased whereas levels of endostatin were elevated after intensive chemotherapy. ${ }^{24}$ On the other hand, our results of significant difference between healthy control and patient groups in PE levels contradicts with the results of the study reported by Lai et al. in patients with AML and MDS. Furthermore, Lai at al. found the significantly lower levels of PE in patients with $\mathrm{CR}$ in comparison to patients without complete remission. However, it was also reported as the limitation of this study that the endostatin assay in this study could not detect the modified or degraded forms of endostatin and it may react differently with various glycosylated forms of endostatin. ${ }^{23}$ This may explain why our results are different from those in the study by Lai et al.

The PE levels of the patients with ALL as well as with AML have been significantly higher than those of control group in our study. However, the PE levels of cases with ALL were not significantly different in pretreatment and remission period in contrast with cases with AML. The elevated levels of PE in cases with acute leukemias during diagnosis are a supporting finding for increasing angiogenesis in bone marrow. Elevated PE levels during remission in comparison to pretreatment period in patients with AML supports the idea that the inhibition of the angiogenesis has a role in remission of patients. Since ALL cases had no differences of PE levels between remission and pretreatment period, it brings to mind that the remission is independent from endostatin dependent angiogenesis. This may lead us to state that treatment of endostatin is less effective in patients with ALL in comparison to patients with AML. Another study which evaluates the cases with ALL has not been found in the literature. Further studies are needed in this subject.

No significant correlation was found between the PE levels and the overall survival or leukemia free survival in both groups with Cox regression analysis. When the patients have been categorized according to plasma endostatin levels $\leq 1.5 />1.5, \leq 2 />2$ and $\leq 2.5 />2.5 \mathrm{ng} / \mathrm{ml}$, the survival of patients whose PE levels are more than $2.5 \mathrm{ng} / \mathrm{ml}$ was found significantly lower than the other group whose PE levels are less than this value only in ALL group. Such a correlation could not be observed in AML group. For this reason pretreatment levels of PE in patients with ALL may be effective in predicting the survival in 
patients with ALL. Larger studies are necessary to confirm this result. The PE levels could not be shown to have a prognostic effect in patients with AML. This finding is different from the ones that have been reported by Lai et al ${ }^{23}$ Lai et al. found that when the mean PE value of control cases were considered as the cut-off value, the survival of the AML patients with PE values higher than the cut off is significantly shorter.

In conclusion we evaluated the plasma levels of endostatin in patients with AML and ALL prior to initiating therapy. We also studied levels of the endostatin in AML and ALL patients after achieving complete remission. We found significantly higher plasma levels of endostatin in patients with AML during CR period and we thought that angiogenesis inhibition with endostatin might have a role to reach CR. This result supports that endostatin has a role in AML treatment. In this study we couldn't show the prognostic importance of plasma levels of endostatin in AML patients. But we found that higher levels of endostatin was associated with shorter survival in ALL. We couldn't find any publication in English literature about the relationship between endostatin levels and ALL prognosis. Our results must be confirmed with large scale studies.

\section{Acknowledgements}

Contributors: All investigators participated in the design of the study and the writing of the paper. Simten Dagdas and Gulsum Ozet interpreted and analyzed data, provided intellectual content and provided critical revision. Simten Dagdas organized and directed the analysis and writing. Mesude Yllmaz contributed to collecting and analyzing data and provided laboratory works. Murat Albayrak and Funda Ceran provided materials or patients collected and assembled data.

We thank to Salih Ergocen for valuable contribution to statistical analysis. We also thank to Deren Laboratory for significant help by opening its laboratory and contribution to laboratory works.

\section{REFERENCES}

1. Risau W. Mechanisms of angiogenesis. Nature 386: 671-674, 1997.

2. Folkman J. Angiogenesis in cancer, vascular, rheumatoid and other disease. Nat Med 1: 27-31, 1995.
3. Papetti M, Herman IM. Mechanisms of normal and tumor derived angiogenesis. Am J Physiol Cell Physiol 282: 947-970, 2002.

4. Feldman AL, Libutti SK. Progress in antiangiogenic gene therapy of cancer. Cancer 89: 1181-1194, 2000.

5. Liu $Y$, Deisseroth $A$. Tumor vascular targeting therapy with vectors. Blood 107: 3027-3033, 2006.

6. Yuan A, Yang PC, Yu CJ, et al. Interleukin-8 messenger ribonucleic acid expression correlates with tumor progression, tumor angiogenesis, patient survival, and timing of relapse in non-small cell lung cancer. Am J Respir Crit Care Med 162: 1957-1963, 2000.

7. Toi M, Hoshina S, Takayanagi T. Association of vascular endothelial growth factor expression with tumor angiogenesis and with early relapse in primary breast cancer. Jpn J Cancer Res 85: 1045-1049, 1994

8. O'Brien T, Cranston D, Fuggle S, Bicknell R, Haris AL. Different angiogenic pathways characterize superficial and invasive bladder cancer. Cancer Res 55: 510513, 1995

9. Takahashi Y, Kitadai Y, Bucana CD, et al. Expression of vascular endothelial growth factor and its receptor, KDR, correlates with vascularity, metastasis, and proliferation of human colon cancer. Cancer Res 55: 3964-3968, 1995

10. Thomas DA, Giles FJ, Cortes J. Antiangiogenesis therapy in leukemia. Acta Haematol 106: 190-207, 2001.

11. Aguayo A, Estey E, Kantarjian $\mathrm{H}$, et al. Cellular vascular endothelial growth factor is a predictor of outcome in patients with acute myeloid leukemia. Blood 94: 3717-3721,1999.

12. Faderl S, Do KA, Johnson MM, et al. Angiogenic factors may have a different prognostic role in adult acute lymphoblastic leukemia. Blood 106: 4303-4307, 2005.

13. Sasaki T, Fukai N, Mann K, et al. Structure, function and tissue forms of the C-terminal globular domain of collogen XVIII containing the angiogenesis inhibitor endostatin. EMBO J 17: 4249-4256,1998.

14. O'Reilly MS, Boehm T, Shing $Y$, et al. Endostatin: an endogenous inhibitor of angiogenesis and tumor growth. Cell 88: 1-20, 1997.

15. Boehm T, Folkman J, Browder T, et al. Antiangiogenic therapy of experimental cancer does not induce acquired drug resistance. Nature 390: 404-407, 1997.

16. Bergers G, Javaherian K, Lo KM, et al. Effects of angiogenesis inhibitors on multistage carcinogenesis in mice. Science 284: 808-812, 1999.

17. Bertolini F, Fusetti L, Mancuso P, et al. Endostatin, an antiangiogenic drug, induces tumor stabilization after chemotherapy or anti-CD20 therapy in a NOD/SCID Mouse model of human high-grade non-Hodgkin lymphoma. Blood 96: 282-287, 2000.

18. Feldman AL, Pak H, Yang JC, et al. Serum endostatin levels are elevated in patients with soft tissue sarcoma. Cancer 91: 1525-1529, 2001.

19. Feldman AL, Tamarkin L, Paciotti GF, et al. Serum endostatin levels are elevated and correlate with serum vascular endothelial growth factor levels in patients 
with stage IV clear cell renal cancer. Clin Cancer Res 6: 4628-4634, 2000.

20. Suzuki M, Lizasa T, Ko E, et al. Serum endostatin correlates with progression and prognosis of non-small cell lung cancer. Lung Cancer 35: 29-34, 2002.

21. Kuroi K, Tanaka C, Toi M. Circulating levels of endostatin in cancer patients. Oncol Rep 8:405-409, 2001.

22. Bono P, Teerenhovi L, Joensuu $H$. Elevated serum endostatin is associated with poor outcome in patients with non-hodgkin lymphoma. Cancer 97: 2767-2775, 2003.

23. Lai R, Estey E, Shen $Y$, et al. Clinical significance of plasma endostatin in acute myeloid leukemia/myelodysplastic syndrome. Cancer 94: 14-17, 2002.

24. Glenjen N, Mosevoll KA, Bruserud O . Serum levels of angiogenin , basic fibroblast growth factor and endostatin in patients receiving intensive chemotherapy for acute myelogenous leukemia. Int J Cancer 101: 86-94,2002.

25. Wrobel T, Mazur G, Kapelko K, et al. Endostatin serum level in acute myeloid leukemia. Neoplasma 52: 182184, 2005.

26. Folkman J. Tumor angiogenesis: therapeutic implications. N Eng J Med 285: 1182-1186., 1971.

27. Yancopoulos GD, Klagsbrun M, Folkman J. Vasculogenesis, angiogenesis and growth factor: ephrins enter the tray at the border. Cell 93: 661-664, 1998.

28. Acenero MJ, Gonzalez JF, Gallego MG, et al. Vascular enumeration as a significant prognosticator for invasive breast carcinoma. J Clin Oncol 16: 1684-1688, 1998.

29. Graham C, Rivers J, Kerbel R, et al. Extent of neovascularization as a prognostic indicator in thin $(<0.76$ mm) melanomas. Am J Pathol 145: 510-514, 1994.

30. Hussong JW, Rodgers GM, Shami PJ. Evidence of increased angiogenesis in patients with acute myeloid leukemia. Blood 95: 309-313, 2000.

31. Pruneri G, Bertolini F, Soligo D, et al. Angiogenesis in myelodysplastic syndromes. Br J Cancer 81: 13981401, 1999.

32. Padro T, Ruiz S, Bieker R, et al. Increased angiogenesis in the bone marrow of patients with acute myeloid leukemia. Blood 95: 2637-2644, 2000.

33. Hamada J, Cavanaugh PG, Lotan O, et al. Separable growth and migration factors for large-cell lymphoma cells secreted by microvascular endothelial cells derived from target organs for metastasis $\mathrm{Br} \mathrm{J}$ Cancer 66: 349-354, 1992.

34. Rak JW, Filmus J, Kerbel RS. Reciprocal paracrineinteractions between tumor cells and endothelial cells: the angiogenesis progression hypothesis. Eur J Cancer 32: 2438-2450, 1996.

35. Poon RT, Fan ST, Wong J. Clinical implications of circulating angiogenic factors in cancer patients. J Clin Oncol 19: 1207-1225, 2001.

36. Kuroi K, Toi M. Circulating angiogenesis regulators in cancer patients. Int J Biol Markers 16: 5-26, 2001.
37. Giles FJ, Vose JM, Do KA, et al. Clinical relevance of circulating angiogenic factors in patients with nonHodgkin's lymphoma or Hodgkin's lymphoma. Leuk Res 28: 595-604, 2004.

38. Bertolini F, Paolucci M, Peccatori F, et al. Angiogenic growth factors and endostatin in non-Hodgkin's lymphoma. Br J Haematol 106: 504-509, 1999.

39. Aguayo A, Kantarjian H, Manshouri T, et al. Angio-genesis in acute and chronic leukemias and myelodysplastic syndromes. Blood 96: 2240-2245, 2000.

40. Salven P. Angiogenesis in lymphoproliferative disorders. Acta Haematol 106: 184-189, 2001.

41. Vacca A, Ribatti D, Ruco L, et al. Angiogenesis extent and macrophage density increase simultaneously with pathological progression in B-cell non-Hodgkin's lymphomas. Br J Cancer 79: 965- 970, 1999.

42. Vacca A, Ribatti D, Roncali L, et al. Bone marrow angiogenesis and progression in multiple myeloma. $\mathrm{Br} \mathrm{J}$ Haematol 87: 503-508, 1994.

43. Hillengass J, Wasser K, Delorme S, et al. Lumbar bone marrow microcirculation measurements from dynamic contrast-enhanced magnetic resonance imaging is a predictor of event-free survival in progressive multiple myeloma. Clin Cancer Res 13: 475-481, 2007.

44. Molica S, Vacca A, Levato D, et al. Angiogenesis in acute and chronic lymphocytic leukemia. Leuk Res 28: 321-324, 2004.

45. Kerbel RS. Clinical trials of antiangiogenic drugs:opportunities, problems, and assesment of initial results. J Clin Oncol 19: 45-51, 2001.

46. Herbst RS, Lee AT, Tran HT, et al. Clinical studies of angiogenesis inhibitors: The University of Texas M.D. Anderson Center Trial of Human Endostatin. Curr Oncol Rep 3: 131-140, 2001.

47. Jung SP, Siegriest B, Hornick CA, et al. Effect of human recombinant endostatin protein on human angiogenesis. Angiogenesis 5: 111-118, 2002.

48. Aref S, El-Sherbiny M, Azmy E, et al. Elevated serum endostatin levels are associated with favorable outcome in acute myeloid leukemia. Hematology 13: 95100, 2008.

\section{Correspondence}

Dr. Simten DAĞDAŞ

Ankara Numune Hastanesi

Hematoloji Bölümü

06100 ANKARA / TURKEY

Tel: (+90.312) 2195599

Mobile: (+90.312) 532.3657251

Fax: (+90.312) 3113187

e-mail: simtendagdas@gmail.com 